\title{
A Study On Influence Of Real Municipal Solid Waste Leachate On Properties Of Soils In Warangal, India
}

\author{
Sudheerkumar Yantrapalli ${ }^{1}{ }^{*}$, Hari Krishna $\mathrm{P}^{2}$, Srinivas $\mathrm{K}^{2}$ \\ ${ }^{1}$ Geotechnical Engineering, NIT Warangal, Warangal, India \\ ${ }^{2}$ Department of Civil Engineering, NIT Warangal, Warangal, India
}

* Corresponding author : sudheerkumar@student.nitw.ac.in

Tel.: +919866938516

Received: Jan 2, 2018. Revised : Feb 22, 2018, Accepted: Feb 26, 2018, Published: 1 March 2018

DOI: 10.24273/jgeet.2018.3.01.1047

\begin{abstract}
Warangal city generates three hundred tons of garbage daily which is dropped into the Rampur dump yard by Warangal Municipal Corporation (WMC). Dumping of wastes will lead to the formation of leachate which in turn will cause environmental issues like soil and ground water contamination. Chemical analysis of leachate indicates that calcium, chloride, sodium and magnesium are the major ions, along with organic content. This leads to contamination of soil as well as ground water bodies. In this study, authors have attempted to know the behavior of soil under the influence of leachate. Contaminated specimens were prepared and tested for Atterberg limits, shear strength, swell potential and hydraulic conductivity of inorganic clays, high plasticity, fat clays (CH) and sand-clay mixtures (SC) which are present in the dumping yard. Index properties, hydraulic conductivity and swell potential decreased with increase in leachate concentration. Unconfined compressive strength also showed an increase. The decrease in hydraulic conductivity indicated the clogging of pores. In a nutshell, the present work deals with the impact of leachate on the index and engineering properties of $\mathrm{CH}$ and red soil.
\end{abstract}

Keywords: Soil Contamination, Leachate, Atterberg limits, Unconfined Compressive Strength (UCS), Swell potential Hydraulic Conductivity.

\section{Introduction}

Rapid industrialization, urbanization and the rise in community living standards have tremendously increased the generation of enormous quantity of municipal solid wastes (Pandey, 2011; Orhan, 2013). Municipal Solid Waste (MSW) is mostly a combination of domestic wastes such as plastic, electrical, battery wastes and industrial wastes which are more aggressive in nature and causes severe contamination to the soil and surrounding water bodies (Uppot and Stephenson, 1989; Khan and Pise, 1994; Soule and Burns, 2001). In order to prevent the adverse effects caused by the unscientific disposal of these wastes, the most common disposal methods employed are incineration, stabilization/ solidification and landfilling. Among all these methods, landfilling is considered to be a safe and economical method to contain the waste (Reddy et al., 2017). Any negligence in waste management will contribute to numerous environmental problems and may even affect living things. Also, soil-leachate interactions may alter the properties of soil (Ramakrishna et al., 2011; Khan et al., 1994). Leachate is a hazardous liquid produced in landfills when moisture interacts with Municipal Solid Waste (MSW) (Sabrina et al., 2013). The major environmental impacts related to landfill leachate are pollution of the surface and sub-surface water (Peter et al., 2013). Previous studies have shown that the soil properties were changed after interacting with leachate (Mesri and Olson, 1970; Sridharan and Venkatappa Rao, 1979; Sridharan et al., 1981; Sivapullaiah and Savitha, 1997; Sunil et al., 2006). Most of the studies were related to the influence of leachate on geotechnical properties such as Atterberg limits and strength properties, while the swelling behavior of the leachate contaminated soil was largely untouched. This paper mainly deals with the influence of MSW leachate on the swelling behavior of locally available soils (CH and SC: Inorganic clays, low to moderate plasticity).

\section{Materials and methodology}

\subsection{Materials}

The material used in this study was collected from NIT Warangal campus and MSW leachate was collected from Rampur open dump yard. The properties of NITW campus soils are presented in table 1 and the soils were classified as highly compressible clay ( $\mathrm{CH}$ ) and clayey sand (SC). The soils used in this study was collected from National Institute of Technology (NIT) Warangal (NITW) campus and MSW leachate was collected from 
Rampur open dump yard in Warangal. The properties of NITW campus soils are presented in Table 1 and the soils were classified as $\mathrm{CH}$ and SC soil. The leachate, collected from the dump yard, was stored at $4^{\circ} \mathrm{C}$ to avoid microbial growth. The leachate composition is presented in Table 2.

Table 1. Properties of soil

\begin{tabular}{lcc}
\hline Parameters & BC soil & Red Earth \\
\hline Gravel (\%) & 4 & 8 \\
Sand (\%) & 26 & 51 \\
Silt (\%) & 30 & 8 \\
Clay (\%) & 40 & 33 \\
Classification & $\mathrm{CH}$ & $\mathrm{SC}$ \\
Specific Gravity & 2.6 & 2.67 \\
Liquid Limit (\%) & 62 & 58 \\
Plastic Limit (\%) & 26 & 24 \\
Plasticity Index (\%) & 36 & 34 \\
MDD (g/cc) & 1.55 & 1.59 \\
OMC (\%) & 24.7 & 23 \\
FSI (\%) & 40 & 30 \\
\hline
\end{tabular}

MDD: Maximum Dry Density,

OMC: Optimum Moisture Content and

FSI: Free Swell Index

Table 2. Chemical composition of landfill leachate

\begin{tabular}{|c|c|c|}
\hline Parameter & $\begin{array}{c}\text { Concentration } \\
(\mathrm{mg} / \mathrm{l})\end{array}$ & Method \\
\hline COD & 50800 & Open reflux \\
\hline BOD & 28000 & Winkler's \\
\hline $\mathrm{EC}$ & 13.62 & Conductivity Meter \\
\hline TDS & 30000 & TDS Meter \\
\hline TSS & 85450 & Filtration \\
\hline TA & 11820 & Phenolphthalein \\
\hline $\mathrm{TH}$ & 112350 & EDTA Titration \\
\hline Chloride & 500 & \\
\hline Sulphate & 72 & 윽 \\
\hline Sodium & 368 & 웡 윽 윽 \\
\hline Potassium & 17 & 帝崫 \\
\hline Calcium & 876 & \\
\hline Magnesium & 318 & \\
\hline Manganese & 67 & ?ำ \\
\hline Ammonium & 48 & 윽 \\
\hline Mercury & 3 & 党 \\
\hline Zinc & 37 & 을 \\
\hline Iron & 67 & 岂 \\
\hline Cobalt & 38 & $\frac{0}{2}$ \\
\hline Lead & 0.7 & \\
\hline $\mathrm{pH}$ & 7 & pH Meter \\
\hline
\end{tabular}

COD: Chemical Oxygen Demand

BOD: Biological Oxygen Demand

EC: Electrical Conductivity (mi Mhor $/ \mathrm{cm}$ )

TDS: Total Dissolved solids

TSS: Total Suspended solids

TA: Total Alkalinity
TH: Total Hardness

\section{Results and Discussions}

\subsection{Atterberg Limits}

Variation of Atterberg limits for two soil samples ( $\mathrm{CH}$ and $\mathrm{SC}$ ) mixed with various percentages of leachate are shown in Figs 2 and 3. The Liquid Limit for uncontaminated $\mathrm{CH}$ soil was observed as $62 \%$ (Fig 2).

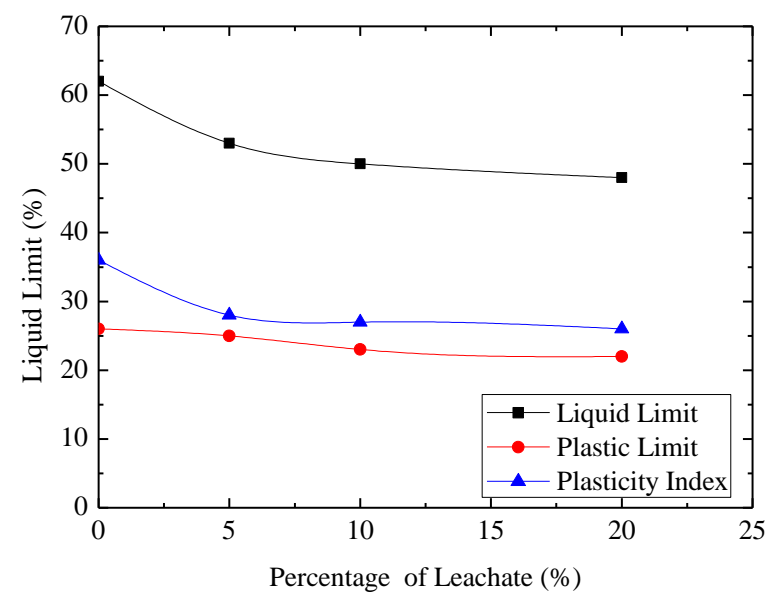

Fig. 2 Variation of Atterberg Limits

Fig. 2 shows that there is a considerable decrease in the liquid limit and plasticity index of the soil after interaction with $5 \%$ percentage of leachate. The results indicate that there is no significant differences between the liquid limit and the plasticity index with the increase in the percentage of leachate.

The Liquid Limit for uncontaminated SC soil was found as 58\%(Fig. 3 ).

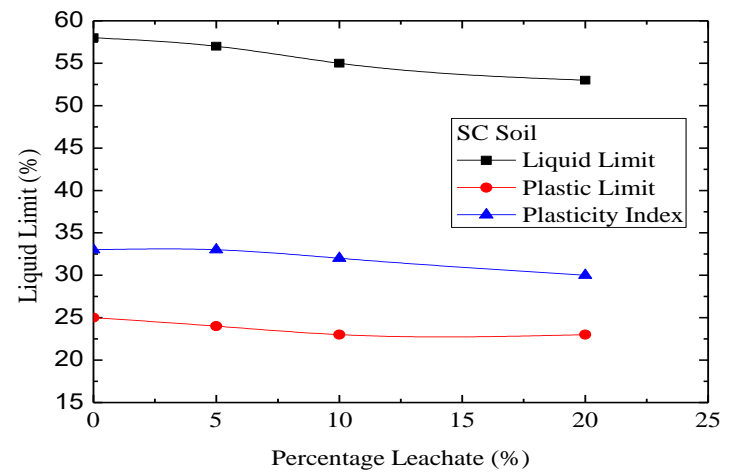

Fig. 3 Variations of Atterberg Limits

After mixing the leachate contaminant to the soil at various percentages $(0 \%, 5 \%, 10 \%$ and $20 \%$ by weight of soil, it was observed that the Liquid Limit showed a decrease with an increase in the concentration of leachate and the variation of these Atterberg limits were slightly less when compared to the $\mathrm{CH}$ soil sample. This decrease in the Atterberg limits are due to the predominant influence of the increased electrolyte concentration and organic chemicals present in the leachate on the diffuse double layer thickness of soil. The reduction in the diffuse double layer thickness of soil caused due to 
the increased electrolyte concentration and the reduction in the inter-particle cohesive nature due to the adsorption of the organic chemicals on the clay particles led to the decrease in the Atterberg Limits (Mathew and Rao, 1997; Eric et al., 2005).

\subsection{Unconfined Compressive Strength}

The variation of unconfined compressive strength (UCS) in Fig. 4 shows value for the two soil samples (CH type and SC type) mixed with various proportions of leachate. It was observed that the uncontaminated $\mathrm{CH}$ soil has a UCS value of $1.7 \mathrm{~kg} / \mathrm{cm}^{2}$. After mixing the leachate with the soil at various percentages $(0 \%, 5 \%$ $10 \%$ and $20 \%$ by weight of soil with a curing period of 3 days, it was observed that there is a slight increase in UCS with increase in percentage of leachate. For uncontaminated SC soil, the unconfined compressive strength (UCS) was observed as $1.66 \mathrm{~kg} / \mathrm{cm}^{2}$.

At $20 \%$ leachate, the increase in strength was $7 \%$ compared with uncontaminated $\mathrm{CH}$ soil, whereas the increase is only $4 \%$ for SC soil. This increase in UCS is due to the electrolyte concentration in the MSW leachate which results in particle aggregation to a flocculated structure, thereby leading to an increase in the UCS of the soil (Mitchell and Soga, 2005).

\subsection{Hydraulic Conductivity}

The hydraulic conductivity $(k)$ test on the soil samples were conducted by using variable head permeameter (IS 2720 Part - 17 and Roque and Didier, 2006). The hydraulic conductivity (k) of $\mathrm{CH}$ soil and SC soil samples were found as $6.8 \times 10^{-7}$ $\mathrm{cm} / \mathrm{sec}$ and $1.7 \times 10^{-4} \mathrm{~cm} / \mathrm{sec}$, respectively after permeating the soil sample with water and $3.2 \times 10^{-7}$ $\mathrm{cm} / \mathrm{sec}$ and $3.4 \times 10^{-5} \mathrm{~cm} / \mathrm{sec}$, respectively after leachate permeation. The percent reduction of hydraulic conductivity for $\mathrm{CH}$ and $\mathrm{SC}$ soil samples were observed as $52 \%$ and $80 \%$ respectively. The reduction of hydraulic conductivity for $\mathrm{CH}$ and $\mathrm{SC}$ soils after interacting with leachate is 52 and 80 percentage respectively.

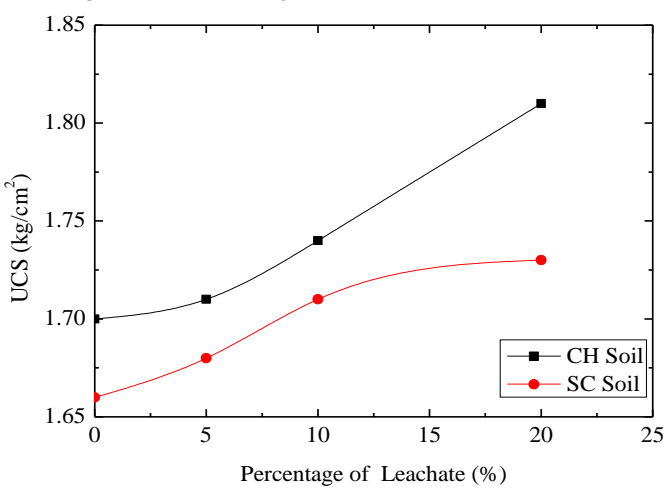

Fig. 4 UCS after interaction with MSW leachate

The reduction in hydraulic conductivity is mainly due to the presence of suspended particles and biological activity (small bacteria) obstructing the flow of leachate through the voids of the soil. Table 3 shows that the reduction in hydraulic conductivity is more in $\mathrm{SC}$ soil when compared to $\mathrm{CH}$ soil. This is due to the formation of more bacterial activity and suspended particles getting accumulated in the bigger void spaces of SC soil.

Table 3 Variation of hydraulic conductivity for $\mathrm{CH}$ and SC soil types with water and leachate.

\begin{tabular}{cccc}
\hline \multirow{2}{*}{$\begin{array}{c}\text { Soil } \\
\text { type }\end{array}$} & \multicolumn{2}{c}{$\begin{array}{c}\text { Hydraulic Conductivity } \\
(\mathrm{k}=\mathrm{cm} / \mathrm{sec})\end{array}$} & $\begin{array}{l}\text { Percentage } \\
\text { Reduction in } \\
\text { hydraulic } \\
\text { conductivity }\end{array}$ \\
\cline { 2 - 4 } & Water & Leachate & 52 \\
$\mathrm{CH}$ & $6.8 \times 10^{-7}$ & $3.2 \times 10^{-7}$ & 50 \\
$\mathrm{SC}$ & $1.7 \times 10^{-4}$ & $3.4 \times 10^{-5}$ & 80 \\
\hline
\end{tabular}

\subsection{Swelling Potential}

The swelling potential tests for the two soil types with water and leachate were conducted in the Teflon made consolidation cell and the variation of the swelling potential of the soils are shown in Table 4.

Table 4. Variation of swelling potential for two soil types with water and leachate.

\begin{tabular}{cccc}
\hline \multirow{2}{*}{$\begin{array}{c}\text { Soil } \\
\text { type }\end{array}$} & \multicolumn{2}{c}{ Swelling potential $(\%)$} & $\begin{array}{c}\text { Decrease in } \\
\text { swelling } \\
\text { potential }\end{array}$ \\
\hline Wh & 22 & Leachate & \\
SC & 9.7 & 6 & 9 \\
\hline
\end{tabular}

It was observed that the decrease in swelling potential for $\mathrm{CH}$ soil was about $9 \%$ more than $\mathrm{SC}$ soil which was about 3.7\% From the results of swelling potential, it is observed that the swelling potential depends on clay content and minerals present in the soil. Thus, the $\mathrm{CH}$ soil is found to be more reactive with leachate than $\mathrm{SC}$ soil.

From Fig 5, it is clear that the percentage swelling for $\mathrm{CH}$ soil with water is $22 \%$ whereas swelling potential with Leachate is reduced to $13 \%$ The decrease in the percentage swell is due to changes in the diffuse double layer repulsive forces caused by the presence of organic chemicals and also due to the smaller dielectric constant of leachate (Foreman and Daniel, 1986; Murat and Mustafa 2009).

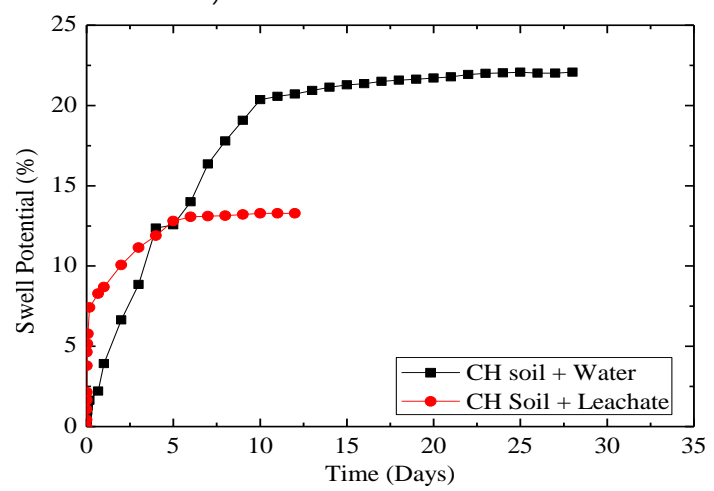

Fig. 5 Variations of swelling potential with water and leachate in $\mathrm{CH}$ soil

Also, it was observed that as the percentage of leachate concentration in the soil increased, the 
plasticity of the soil was reduced simultaneously. Since swelling is a function of plasticity, the swelling potential is reduced.

It was observed from Fig 6, that the swelling potential for SC soil with water is $9.7 \%$ whereas percent swell with leachate is decreased to $6 \%$ The changes in swelling in the soils might be due to changes in repulsive forces and the reduction in the plasticity of the soil. When compared to the SC soil, the $\mathrm{CH}$ soil shows more swelling and after interacting with leachate, the swelling of both $\mathrm{SC}$ and $\mathrm{CH}$ soils reduced significantly.

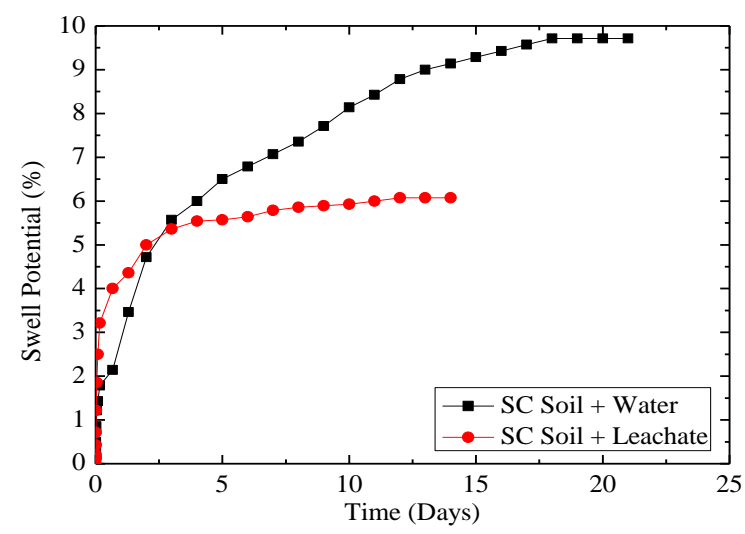

Fig. 6 Variations of swelling potential with water and leachate in SC soil

\subsection{Scanning Electron Microscope (SEM)}

The uncontaminated soil samples and samples contaminated with leachate were collected from the oedometer after completion of the swell tests. These collected samples were tested for morphological changes. The results are as shown in Fig. 7a and 7b.

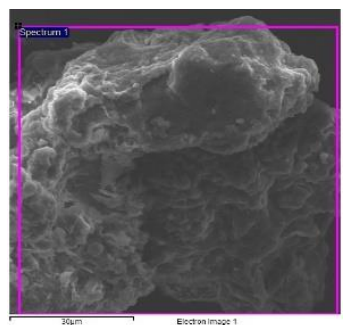

Uncontaminated Soil

Fig. 7a SEM of $\mathrm{CH}$ soil

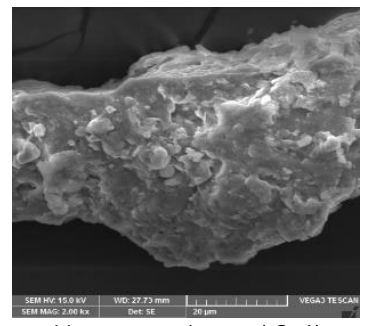

Uncontaminated Soil

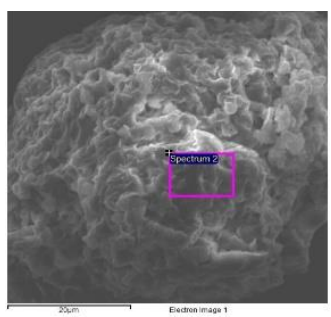

Contaminated Soil

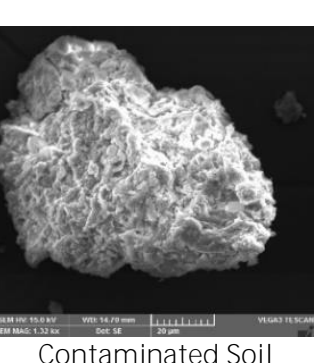

Contaminated Soil

Fig. 7b SEM of SC soil

The SEM images of the contaminated and uncontaminated soil samples of $\mathrm{CH}$ and SC soils show the changes in the morphology of the soil particle after interacting with the leachate. The morphology of both the soils are associated with the arcuate steps, imbricated blocks, fractured plates, meandering ridges and irregular depressions which indicate the aggregation of the soil particles. This leads to the decrease in the plasticity index and the swell potential and the increase in the Unconfined Compressive Strength (UCS) of the leachate contaminated soil when compared to uncontaminated soil.

\section{Conclusions}

From the above experimental study, it is concluded that the liquid limit and plasticity index decrease with an increase in the percentage of leachate. These changes are more for the $\mathrm{CH}$ soil sample than SC soil sample. The Unconfined Compressive Strength (UCS) also showed an increase with the presence of leachate for both $\mathrm{CH}$ and SC soil samples. The hydraulic conductivity of the soil after permeating with leachate decreased due to the blockage of pores by leachate and the hydraulic conductivity of $\mathrm{CH}$ soil is well within the range of USEPA specified liner material requirement (i.e. $<1 \times$ $10^{-7} \mathrm{~cm} / \mathrm{sec}$ ). The swelling potential with water for $\mathrm{CH}$ soil was more than for SC soil. The decrease in swelling potential with leachate for $\mathrm{CH}$ soil was more than that for SC soil. From the above study, it is concluded that the landfill leachate was more reactive with $\mathrm{CH}$ soil than $\mathrm{SC}$ soil and it persisted its hydraulic conductivity after interaction with leachate.

\section{REFERENCES}

Eric M.F., Ernest K., Yanful,. 2008. Interactions between three tropical soils and municipal solid waste landfill Leachate. Journal of Geotechnical and Geo-environmental Engineering134, 379 395.

Foreman, D.E., Daniel, D.E., 1986. Permeation of compacted clay with organic chemicals. Journal of Geotechnical Engineering, ASCE 112 (7), 669-681.

IS 2720-10., Methods of test for soils, Part 10. Determination of unconfined compressive strength.

IS 2720-4., Methods of test for soils, Part 4. Grain size analysis.

IS 2720-5., Methods of test for soils, Part 5 Determination of liquid and plastic limit.

Khan, A.K., Pise, P.J., 1994. Effect of liquid wastes on the physico-chemical properties of lateritic soils. Proceedings of Indian Geotechnical Conference, 189-194.

Khan, S.A., Rao, C.U., Bandyopadhyay, M., 1994. Characteristics of leachates from solid wastes. Indian Journal of Environmental Health 36 (4), 248-257.

Mathew P.K., Rao, S.N., 1997. Influence of cations on compressibility behaviour of a marine clay. 
Journal of Geotechnical Engineering 123 (11), 1071-1073.

Mesri, G., Olson, R.E., 1970. Shear strength of Montmorillonite. Geotechnique 20 (3), 261-270.

Mitchell, J. K and Soga, K., 2005. Fundamentals of soil behavior. John Wiley \& Sons, Inc., New York, N.Y.

Murat, O., Mustafa, Y., 2009. Effect of organic fluids on the Geotechnical behavior of a highly plastic clayey soil. Journal of Applied Clay Science, 48, 615 $-621$.

Orhan, A., 2013. Municipal solid waste landfill site selection using geophysical information system: a case study from corlu, Turkey". Arob journal of Geoscience.

Pandey, P.C., Sharma, K.L., and Nathawat, M. S., 2011. Geospatial strategy for sustainable management of municipal solid waste for growing urban environment. Environ Monit Assess, 184, 24192431.d

Peter, K., Morton, A.B., Alix, P.R., Anders, B., Anna, L and Thomas, H.C., 2013. Present and Long-Term Composition of MSW Landfill Leachate: A Review. Critical Reviews in Environmental Science and Technology, 32(4), 297-336.

Ramakrishna, G.C., Ramakrishna, Y., Shiva Shankar, R., Sivapullaiah, P.V., 2011. Geotechnical properties of Shedi soil affected by Alkali contamination. International Journal of Environmental Protection 4, 45-52.

Reddy, K.R., Girish, K., and Rajiv, K.G., 2017 System Effects on Bioreactor Landfill Performance Based on Coupled Hydro-Bio-Mechanical Modeling. Journal of Hazardous, Toxic, and Radioactive Waste, 22 (1), 1 - 15.
Roque, A.J., and Didier, G., 2006. Calculating hydraulic conductivity of fine grained soils to leachates using linear expressions. Journal of Engineering Geology, UK85 (1), 147-157.

Sabrina, L. B., and Craig, H. B., 2013. Effect of Municipal Solid Waste Leachate on Hydraulic Conductivity and Exchange Complex of Geosynthetic Clay Liners. Journal of Geotechnical and Geo-environmental Engineering, 140 (4), 1 - 17.

Sivapullaiah, P.V., Savitha, S., 1997. Performance of bentonite clay liner with electrolytic leachates. Proc. of Indian Geotechnical Conference, Vododara, India, 363-366.

Soule, N. M., and Burns, S. E., 2001. Effects of organic cation structure on behavior of organobentonites. Journal of Geotechnical and Geo-environmental Engineering, ASCE 127 (4), 363-370.

Sridharan, A., Nagaraj, T. S., and Sivapullaiah, P.V., 1981. Heaving of soil due to acid contamination. Proc. of International Conference on Soil Mechanics Foundation Engineering, vol. 2, pp. 383-386. Balkema, Stockholm.

Sridharan, A., and Venkatappa Rao, G., 1979. Shear strength behaviour of saturated clays and the role of the effective stress concept. Geotechnique 29 (2), 177-193.

Sunil, B M., Sitaram, N S., and Srihari., 2006. Effect of $\mathrm{pH}$ on Geotechnical properties of laterite soils. Journal of Engineering Geology, vol. 85, pp 197203.

Uppot, J. O., and Stephenson, R.W., 1989. Permeability of clays under organic permeants. Journal of Geotechnical Engineering, ASCE 115 (1), 115-131. 